\title{
Prevalensi Anemia, Status Gizi dan Kebiasaan Makan Pagi pada Anak Sekolah Dasar di Kecamatan Bukit Raya Kota Pekanbaru
}

\section{Prevalence of Anemia, Nutrition Status and Breakfast Habit on Elementary School Children in Bukit Raya sub-distric of Pekanbaru}

Sri Desfita

Pusat Penjaminan Mutu Internal STIKes Hang Tuah Pekanbaru

\section{ABSTRAK}

Anemia pada anak sekolah dasar masih menjadi masalah kesehatan masyarakat di Indonesia. Menurut Survei Kesehatan Rumah Tangga (SKRT) tahun 2004 prevalensi anemia pada anak usia 5-11 tahun sebesar 24\%. Sementara itu Lembaga Swadaya Masyarakat (LSM) asing Mercy Corps. (2005) melaporkan bahwa prevalensi anemia pada anak sekolah dasar di Riau sebesar 55,6\%. Survei tersebut juga melaporkan bahwa 35\% anak sekolah dasar di Riau mengalami status gizi pendek. Kebiasaan makan pagi merupakan faktor determinan anemia dan status gizi. Penelitian ini bertujuan untuk mengetahui prevalensi anemia, status gizi dan kebiasaan makan pagi pada anak sekolah dasar di Kota Pekanbaru. Jenis penelitian adalah observasional dengan rancangan crossectional. Subjek penelitian adalah anak sekolah dasar usia 10-12 tahun di Kota Pekanbaru sebanyak 95 anak. Pemilihan sekolah dasar berdasarkan teknik multi stage cluster sampling, dan subjek penelitian dari sekolah dasar dipilih berdasarkan kriteria usia 10-12 tahun. Variabel penelitian adalah status anemia, status gizi berdasarkan antropometri dengan indikator Berat Badan menurut Umur (BB/U), Tinggi Badan menurut Umur $(\mathrm{TB} / \mathrm{U})$ dan Berat Badan menurut Tinggi Badan (BB/TB) dan kebiasaan makan pagi. Data status anemia diukur melalui pemeriksaan dengan metode STAT SITE MHgb, status gizi diukur dengan timbangan digital dan microtoice, kebiasaan makan pagi diperoleh melalui kuesioner. Data dianalisis secara univariat dalam bentuk tabel distribusi frekuensi. Prevalensi anemia pada anak sekolah dasar di Kecamatan Bukit Raya adalah 34,2\%. Prevalensi status gizi kurang sebesar 15,2\%, kurus 0,8\% dan pendek 19,7\%. Kebiasaan makan pagi jarang sebanyak 41,7\%. Prevalensi anemia pada anak sekolah dasar di Kecamatan Bukit Raya termasuk tingkat sedang. Prevalensi status gizi kurang pada anak sekolah dasar termasuk rendah. Masih banyak ditemukan anak sekolah dasar yang jarang makan pagi.

Kata Kunci: Anemia, Status Gizi, Kebiasaan Makan Pagi

\section{ABSTRACT}

Anemia on elementary school children is still a major health problem in Indonesia. The Prevalence of anemia according to Household Health Survey 2004 is 24\% for children of 5-11 years old. Mercy Corps survey (2005) showed that prevalence of anemia is 55,6\% for elementary school children in Riau. The survey also reported that nutrition status of school children based on height/age is 35\% stunted. Breakfast habit is a determinant factor of anemia and nutrition status. The objective of this study is to know the prevalence of anemia, nutrition status, and breakfast habit on elementary school children in Pekanbaru. The study was observational with cross sectional design. Subject of the study based on inclusion criteria were the elementary school children aged 10-12 years old in Pekanbaru City. Total numbers of subjects were 95 children. The elementary schools were elected based on multi stage cluster sampling. Subjects of this study were based on inclusion criteria. The variable of the study were anemia status, nutrition status based on anthropometry method with indicator of weight for age, weight for height, and height for age, and breakfast habit. Data of anemia status was measured with STAT SITE MHgb method. Data of nutrition status was measured with digital health scale and microtoice. Data of breakfast habit was obtained from questionnaire. Data was analysed with univariate analysis. Prevalence of anemia in elementary school children was $34,2 \%$, the prevalence of under nutrition was 15,2\% (under weight), 0,8\% (wasted), and 19,7\% (stunted). Less breakfast habit of school children was 41,7\%. The prevalence of anemia in elementary school children in Bukit Raya Subdistrict was classified as moderate level. The prevalence of under nutrition status was low level. There were still found some elementary school children who were rarely doing their breakfast.

Key words: Anemia, Nutrition Status, Breakfast Habit

\section{PENDAHULUAN}

Indonesia masih menghadapi masalah kekurangan gizi. Hal ini terkait erat dengan tingkat kesejahteraan masyarakat yang masih rendah. Salah satu kelompok rawan gizi adalah anak usia sekolah. Kekurangan gizi pada anak sekolah.

berpengaruh terhadap tingkat kecerdasan. Dampak jangka panjang dari kekurangan gizi ini adalah rendahnya kualitas Sumber Daya Manusia (SDM) yang akhirnya akan menghambat pembangunan nasional.

Alamat Korespondesi: Sri Desfita, Pusat Penjaminan Mutu Internal STIKes Hang Tuah Pekanbaru, Jalan Mustafa Sari No 5 Tangkerang Selatan Pekanbaru Riau, Hp 081365321583.email: dear_deshi@yahoo.com 
Anemia, status gizi yang kurang serta kebiasaan makan pagi yang jarang merupakan faktor-faktor yang dapat menghambat kemampuan belajar anak sehingga berdampak pada tingkat kecerdasan.

Prevalensi anemia pada anak sekolah dasar masih tinggi. Berdasarkan Survei Kesehatan Rumah Tangga (SKRT) tahun 2004 prevalensi anemia pada anak usia 5-11 tahun sebesar 24\%. Menurut survei yang dilakukan oleh Mercycorps (2005) prevalensi anemia pada anak sekolah dasar di Riau sebesar $55,6 \%$. Prevalensi ini lebih tinggi bila dibandingkan dengan prevalensi anemia di Sumatra Barat yaitu 43,34\% dan Bengkulu 26\%. Survei tersebut juga melaporkan bahwa 35\% anak sekolah di Riau mengalami status gizi kurang.

Kebiasaan makan pagi merupakan faktor determinan anemia dan status gizi (Irawati, 2000). Menurut Badan Pusat Statistik (BPS) (2006), ditemukan hanya $15 \%$ anak sekolah dasar yang mempunyai kebiasaan makan pagi di Kabupaten Majalengka. Penelitian Kurniasari (2005) di Yogyakarta menemukan sebesar $75 \%$ anak sekolah dasar mempunyai kebiasaan makan pagi yang sering. Kebiasaan makan pagi pada anak sekolah dasar di Kecamatan Bukit Raya, Kota Pekanbaru belum diketahui.

Anak sekolah dasar berada pada masa pertumbuhan. Anak membutuhkan zat-zat gizi yang cukup untuk mendukung tumbuh kembangnya. Bila terjadi gangguan gizi pada anak, pertumbuhan dan perkembangan anak menjadi tidak optimal. Anak memiliki kemampuan yang rendah untuk menyerap pengetahuan yang diberikan di sekolah. Hal ini tentu akan mempengaruhi tingkat kecerdasan anak. Berdasarkan hal ini perlu diketahui faktor-faktor yang dapat menghambat kemampuan belajar anak sekolah dasar seperti anemia, status gizi dan kebiasaan makan pagi di Kecamatan Bukit Raya, Kota Pekanbaru, sehingga diharapkan dapat menghasilkan rumusan kebijakan yang tepat untuk mengatasi masalah gizi pada anak sekolah dasar.

\section{METODE}

Jenis penelitian ini adalah observasional dengan rancangan penelitian cross-sectional. Penelitian dilaksanakan di Kecamatan Bukit Raya, Kota Pekanbaru, Provinsi Riau pada bulan Mei sampai Juni 2008.

Populasi adalah anak sekolah dasar usia 10 sampai 12 tahun di Kecamatan Bukit Raya, Kota Pekanbaru. Subjek penelitian adalah anak sekolah dasar usia 10 sampai 12 tahun dengan kriteria eksklusi tidak menderita sakit pada saat penelitian. Subjek penelitian berasal dari 2 SD Negeri yaitu SD Negeri 025 Kelurahan Tangkerang Selatan dan SD Negeri 052 Kelurahan Simpang Tiga. Jumlah subjek penelitian adalah 132 anak yang terdiri dari 48 anak berasal dari
SD Negeri 025 dan 84 anak berasal dari SD Negeri 052 .

Variabel penelitian adalah status anemia, status gizi dan kebiasaan makan pagi. Data kadar hemoglobin diperoleh melalui pemeriksaan dengan metode STAT SITE MHgb. Data berat badan diperoleh dengan penimbangan berat badan menggunakan timbangan digital seca dengan ketelitian $0,1 \mathrm{~kg}$. Data tinggi badan menggunakan microtoise dengan ketelitian 0,1 cm. Data kebiasaan makan pagi diperoleh melalui wawancara dengan menggunakan kuesioner.

Pengolahan data menggunakan program komputer. Data dianalisis secara kuantitatif menggunakan analisis univariat dalam bentuk tabel distribusi frekuensi. Analisis ini untuk menggambarkan prevalensi anemia, status gizi dan kebiasaan makan pagi pada anak sekolah dasar di Kecamatan Bukit Raya, Kota Pekanbaru.

\section{HASIL}

\section{Status Anemia}

Data anemia hanya dapat diperoleh dari 76 subjek. Hal ini karena keterbatasan reagen untuk pemeriksaan kadar $\mathrm{Hb}$. Subjek terdiri dari 41 anak berasal dari SD Negeri 025, Kelurahan Tangkerang Selatan dan 35 anak berasal dari SD Negeri 052, Kelurahan Simpang Tiga, Kecamatan Bukit Raya. Prevalensi anemia sebesar 34,2\%. Perbedaan proporsi sebesar 7,6\% pada kejadian anemia berdasarkan jenis kelamin (lihat tabel 1,2 dan 3).

Tabel 1

Distribusi Siswa Berdasarkan Status Anemia

\begin{tabular}{lcc}
\hline \multicolumn{1}{c}{ Status anemia } & Frekuensi & Persen (\%) \\
\hline Anemia & 26 & 34,2 \\
Tidak anemia & 50 & 65,8 \\
\hline
\end{tabular}

Tabel 2

Distribusi Siswa Berdasarkan Asal SD

\begin{tabular}{|c|c|c|c|c|c|c|}
\hline \multirow[t]{2}{*}{ Asal SD } & \multicolumn{2}{|c|}{ Anemia } & \multicolumn{2}{|c|}{$\begin{array}{c}\text { Tidak } \\
\text { Anemia }\end{array}$} & \multicolumn{2}{|c|}{ Total } \\
\hline & $\mathbf{n}$ & $\%$ & $\mathrm{n}$ & $\%$ & $\mathbf{N}$ & $\%$ \\
\hline SDN 025 & 15 & 36,6 & 26 & 63,4 & 41 & 100 \\
\hline SDN 052 & 11 & 31,4 & 24 & 68.6 & 45 & 100 \\
\hline
\end{tabular}

Tabel 3

Distribusi Anemia Berdasarkan Jenis Kelamin

\begin{tabular}{lcc}
\hline \multicolumn{1}{c}{ Jenis kelamin } & Frekuensi & Persen (\%) \\
\hline Laki-laki & 12 & 46,2 \\
Perempuan & 14 & 53,8 \\
Total & 26 & 100 \\
\hline
\end{tabular}

\section{Status Gizi dan Kebiasaan Makan Pagi}

Status gizi subjek berdasarkan antropometri dengan menggunakan indeks Berat Badan menurut Umur $(\mathrm{BB} / \mathrm{U})$, Berat Badan menurut Tinggi Badan 
(BB/TB) dan Tinggi Badan menurut Umur (TB/U) dapat dilihat pada tabel 6 .

Tabel 4

Distribusi Subjek Berdasarkan Status Gizi

\begin{tabular}{crrr}
\hline No. & Status Gizi & Frekuensi & $\begin{array}{c}\text { Persen } \\
(\%)\end{array}$ \\
\hline 1. & BB/U & & \\
a. Gizi lebih & 2 & 1,5 \\
b. Gizi baik & 110 & 83,3 \\
c. Gizi kurang & 20 & 15,2 \\
2. & BB/TB & & \\
a. Gemuk & 6 & 4,5 \\
b. Normal & 125 & 94,7 \\
3. TB/U Kurus & 1 & 0,8 \\
& a. Pendek & 26 & 19,7 \\
b. Normal & 106 & 80,3 \\
& Total & 132 & 100 \\
\hline
\end{tabular}

Tabel 5

Distribusi Subjek Berdasarkan Kebiasaan Makan Pagi

\begin{tabular}{cccc}
\hline No. & $\begin{array}{c}\text { Kebiasaan Makan } \\
\text { Pagi }\end{array}$ & Frekuensi & $\begin{array}{c}\text { Persen } \\
(\%)\end{array}$ \\
\hline 1. & Jarang & 55 & 41,7 \\
2. & Sering & 77 & 58,3 \\
\hline
\end{tabular}

\section{PEMBAHASAN}

Anemia

Prevalensi anemia pada anak SD dalam penelitian ini ditemukan sebesar $34,2 \%$. Kondisi ini menunjukkan anemia pada anak SD sebagai masalah kesehatan masyarakat tingkat sedang. Bila dibandingkan dengan prevalensi anemia pada anak SD menurut SKRT tahun 2004, besaran prevalensi pada penelitian ini lebih tinggi sebesar $10,2 \%$. Namun bila dibandingkan dengan prevalensi anemia temuan Mercycorps. (2005), angka prevalensi ini lebih rendah. Prevalensi anemia pada anak SD di Riau menurut survei Mercycorps. (2005) sebesar 55,6\%. Hasil dari berbagai survei tersebut, menegaskan bahwa anemia masih menjadi masalah kesehatan masyarakat di Indonesia. Menurut WHO (2008) anemia dikatakan tidak menjadi masalah kesehatan masyarakat bila prevalensinya $\leq 4,9 \%$.

Anemia merupakan masalah kesehatan global baik di negara berkembang maupun di negara maju. Anemia dapat terjadi pada semua golongan usia. Anak-anak merupakan salah satu kelompok yang rawan terhadap anemia. Prevalensi anemia pada anak sekolah di dunia menurut WHO (2008) adalah 25,4\%.

Anemia disebabkan oleh banyak faktor yang dapat terjadi secara bersamaan pada satu individu. Penyebab utama anemia adalah defisiensi zat besi. Prevalensi anemia digunakan sebagai indikator proksi (wakil) dari defisiensi zat besi. Diasumsikan bahwa $50 \%$ kasus anemia disebabkan oleh defisiensi zat besi. Penyebab defisiensi zat besi ini antara lain rendahnya asupan zat besi, rendahnya absorpsi zat besi di usus halus karena diet yang tinggi asam fitat dan senyawa fenol. Defisiensi mikronutrien lainnya seperti vitamin A, $B_{12}$, folat, riboflavin dan tembaga dapat meningkatkan risiko anemia. Penyebab anemia lainnya seperti infeksi cacing tambang dan ascaris dapat menurunkan kadar hemoglobin (Hb) (WHO, 2008). Terjadinya anemia pada anak SD di Kecamatan Bukit Raya ini dapat disebabkan oleh faktor-faktor tersebut di atas.

Anak yang mengalami anemia menunjukkan gejala pucat, lemah, lelah, menurunnya kemampuan atau konsentrasi belajar, menurunnya antibodi sehingga mudah terserang infeksi. Defisiensi zat besi pada anak yang anemia juga berdampak pada perkembangan mentalnya. Indeks perkembangan psikomotor pada anak yang anemia lebih rendah daripada anak yang sehat. Prestasi sekolah (school achievement test) umumnya juga lebih rendah dibanding anak yang tidak anemia (Muhilal \& Damayanti, 2006).

Distribusi anemia berdasarkan asal SD menunjukkan bahwa SD Negeri 025 memiliki prevalensi anemia yang sedikit lebih tinggi dibandingkan dengan SD negeri 052. Baik SD Negeri 025 maupun SD Negeri 052 berada di wilayah yang secara geografis dan demografis memiliki karakteristik yang relatif sama.

Pada 26 anak yang mengalami anemia, sebesar $53,8 \%$ berjenis kelamin perempuan. Penelitian Hastono (2000) mengenai faktor-faktor yang berhubungan dengan anemia pada anak sekolah dasar di Provinsi Lampung menyatakan faktor yang paling berhubungan dengan kejadian anemia adalah variabel jenis kelamin. Perempuan memiliki risiko anemia lebih tinggi dibanding laki-laki.

Penanggulangan anemia dapat dilakukan dengan berbagai upaya bergantung pada penyebab terjadinya anemia tersebut. Bila anemia disebabkan oleh pola konsumsi yang tidak adekuat maka perlu diupayakan perubahan pola konsumsi melalui metode penyuluhan. Pemberian suplementasi zat besi terbukti dapat memperbaiki keadaan anemia. Bila anemia disebabkan karena infeksi cacing, pemberian obat cacing secara berkala perlu dilakukan di samping memberikan penyuluhan tentang pentingnya menjaga higiene dan sanitasi lingkungan. Penelitian ini tidak melihat faktor-faktor yang mempengaruhi terjadinya anemia pada anak SD.

\section{Status Gizi Dan Kebiasaan Makan Pagi}

Prevalensi status gizi kurang $(\mathrm{BB} / \mathrm{U})$ pada penelitian ini sebesar $15,2 \%$, kurus $(\mathrm{BB} / \mathrm{TB}) 0,8 \%$ dan pendek (TB/U) 19,7\%. Data ini mencerminkan kekurangan gizi masih terjadi pada anak sekolah dasar walaupun prevalensinya termasuk rendah. Berbeda dengan hasil survei Mercycorps. (2005) di Provinsi Riau yang menemukan prevalensi status gizi kurang $25,35 \%$, kurus $3,42 \%$ dan pendek $28,37 \%$. 
Mercycorps. (2005) melakukan survei di Kecamatan Rumbai Kota Pekanbaru dan di Kabupaten Kampar. Indikator $\mathrm{BB} / \mathrm{U}$ mencerminkan status gizi kurang saat ini dan bila dilakukan berulang dapat mendeteksi growth failure karena infeksi atau Kekurangan Energi Protein (KEP). TB/U merupakan indikator status gizi masa lalu dan dapat menggambarkan kesejahteraan dan kemakmuran suatu bangsa. Indikator $\mathrm{BB} / \mathrm{TB}$ menunjukkan status gizi saat ini dan dapat mengetahui proporsi tubuh kurus, normal atau gemuk (Hartriyanti \& Triyanti, 2007).

Kebiasaan makan pagi termasuk ke dalam salah satu 13 pesan dasar gizi seimbang. Bagi anak sekolah, makan pagi dapat meningkatkan konsentrasi belajar dan memudahkan menyerap pelajaran sehingga meningkatkan prestasi belajar (Depkes, 2002). Penelitian ini menemukan $41,7 \%$ subjek jarang makan pagi. Hal ini disebabkan karena subjek tidak memiliki cukup waktu untuk makan pagi.

Terdapat beberapa alasan untuk tidak makan pagi seperti tidak lapar, tidak ada waktu, tidak ada yang menyiapkan makanan, tidak suka makanan yang disiapkan, makanan tidak ada dan sebagainya (Muhilal \& Damayanti, 2006). Penelitian Kurniasari (2005) di Yogyakarta menunjukkan 25\% anak SD jarang makan pagi dengan alasan tidak sempat, tidak terbiasa dan tidak selera. Berdasarkan laporan BPS Kabupaten Majalengka (2006), hanya $15,2 \%$ anak SD yang mempunyai kebiasaan makan pagi. Pada umumnya anak sudah diberi uang jajan sementara makanan yang dijajakan di sekolah kurang terjamin kandungan gizinya.

Makan pagi dapat menyumbang seperempat dari kebutuhan gizi sehari yaitu sekitar 450-500 kalori dengan 8-9 gram protein. Selain kandungan gizinya cukup, bentuk makan pagi sebaiknya juga disukai anak-anak dan praktis pembuatannya (Muhilal \& Damayanti, 2006).

Kebiasaan makan pagi dapat berkontribusi terhadap status gizi anak. Anak yang biasa makan pagi akan dapat memenuhi kebutuhan gizinya dalam sehari. Penelitian Irawati (2000) menemukan anak yang tidak biasa makan pagi berisiko terhadap status gizi kurang.

Kekurangan gizi menyebabkan anak mudah lelah, tidak kuat melakukan aktivitas fisik yang lama, tidak mampu berpikir dan berpartisipasi penuh dalam proses belajar. Risiko untuk menderita penyakit infeksi lebih besar pada anak yang kurang gizi, sehingga tingkat kehadirannya rendah di sekolah (Muhilal \& Damayanti, 2006).

Pengaturan makan untuk anak usia sekolah bertujuan membentuk kebiasaan makan yang baik dan berpartisipasi dalam aktivitas olahraga secara teratur, guna mencapai perkembangan fisik dan kognitif yang optimal, berat badan yang normal, menikmati makanan dan menurunkan risiko menderita penyakit kronis (Muhilal \& Damayanti, 2006).

\section{KESIMPULAN}

Prevalensi anemia pada anak sekolah dasar di Kecamatan Bukit Raya termasuk tingkat sedang. Prevalensi status gizi kurang pada anak sekolah dasar termasuk rendah. Masih banyak ditemukan anak sekolah dasar yang jarang makan pagi.

\section{SARAN}

Penyuluhan tentang gizi, higiene dan sanitasi lingkungan pada anak sekolah dasar perlu dipertimbangkan oleh pihak sekolah untuk mencegah terjadinya anemia. Perlu dilakukan penelitian lebih lanjut dengan jumlah subjek yang lebih besar untuk melihat faktor-faktor yang berhubungan dengan terjadinya anemia pada anak sekolah dasar, serta hubungan anemia dengan konsentrasi dan prestasi belajar di Kecamatan Bukit Raya.

\section{UCAPAN TERIMA KASIH}

Peneliti mengucapkan terima kasih kepada seluruh siswa yang telah berpartisipasi dalam penelitian ini, kepada Kepala Dinas Pendidikan dan Olah Raga Kota Pekanbaru dan kepada Kepala Sekolah SDN 025 Tangkerang Selatan dan SDN 052 Simpang Tiga yang telah bersedia dijadikan lokasi penelitian.

\section{DAFTAR PUSTAKA}

Badan Pusat Statistik (BPS) (2006) Analisis Situasi Ibu dan Anak (ASIA) Kabupaten Majalengka.

Departemen Kesehatan RI. (2002). Pedoman Umum Gizi Seimbang.

Hartriyanti \& Triyanti (2007) Gizi dan Kesehatan Masyarakat. Jakarta: Rajawali Pers.

Hastono S.P. (2000) Pemodelan Regresi Logistik untuk Identifikasi Faktor-Faktor yang Berhubungan dengan Anemia pada Anak Sekolah Dasar di Propinsi Lampung. Laporan Penelitian, Universitas Indonesia.

Irawati (2000) Faktor Determinan Status Gizi dan Anemia Murid SD di Desa IDT Penerima $P M T-A S$ di Indonesia. Bogor: Pusat Penelitian dan Pengembangan Gizi, Badan Penelitian dan Pengembangan Kesehatan.

Kurniasari, R. (2005) Hubungan Frekuensi dan Asupan Gizi Makan Pagi dengan Kadar Hemoglobin (Hb) Darah dan Konsentrasi di Sekolah pada Murid Kelas V dan VI SDN Jetis 1 dan SDN Jetishardjo 1 Yogyakarta. Tesis, Universitas Gadjah Mada.

Lemeshow, S., Hosmer Jr, D.W., Klar, J., Wanga, S.K.L. (1990) Adequacy Of Sample Size in 
Sample Size in Health Studies, Pramono, D. (1997) (alih bahasa) Yogyakarta: Gadjah Mada University Press; 1997.

Mercy Corps. (2005) Program Kesehatan Sekolah Mercy Corps di Sumatra (Sumatra Healthy Schools Program (SHSP)): Hasil Kajian untuk Propinsi Riau.

Muhilal \& Damayanti, D. (2006) Gizi seimbang untuk Anak Usia Sekolah Dasar. In : Soekirman,
Susana, H., Giarno, M.H. \& Lestari Y. eds. Hidup Sehat: Gizi Seimbang dalam Siklus Kehidupan Manusia. Jakarta: Primamedia Pustaka.

WHO (2008) Worldwide Prevalence of Anaemia 1993-2005. WHO Global Database on Anaemia. 